\title{
Horizontal heterogeneity of seston, organic carbon and picoplankton in the photic zone of Lago Maggiore, Northern Italy
}

\author{
Roberto BERTONI*, Roberta PISCIA and Cristiana CALLIERI \\ CNR Istituto per lo Studio degli Ecosistemi, Sezione di Idrobiologia ed Ecologia delle Acque Interne, Largo Tonolli 50, 28922 \\ Verbania Pallanza, Italy \\ *e-mail corresponding author: r.bertoni@ise.cnr.it
}

\begin{abstract}
The horizontal heterogeneity of seston, dissolved (DOC) and particulate (POC) organic matter, Chlorophyll-a (Chl) and of autotrophic (APP) and heterotrophic (HPP) picoplankton was evaluated seasonally during a two-year period in Lago Maggiore, a large deep oligotrophic lake in Northern Italy. The dissolved fraction resulted homogeneously distributed in the epilimnion during the whole sampling period. The particulate fraction showed the higher heterogeneity in winter 2000 and 2001. For those years, POC and Chl heterogeneity was, respectively, 3-5 and 5-7 times higher than DOC. A similar trend was evident for Chl and for APP. The spatial heterogeneity of HPP resulted always smaller than the analytical variability, thus preventing any consideration about the spatial distribution of HPP. POC and Chl concentration exhibited a recurrent pattern of their spatial heterogeneity, possibly in relation with the location of the part of the drainage basin conveying higher amounts of nutrients to the lake.
\end{abstract}

Key words: TOC, picoplankton, horizontal distribution

\section{INTRODUCTION}

Spatial heterogeneity, or patchiness, has long been recognized in biological communities of lakes (Downing 1991) such as phytoplankton (Platt et al. 1970; George \& Heaney 1978) and zooplankton (George \& Jones 1987; Laybourn Parry et al. 1990; Malone \& McQueen 1983). Its occurrence has been attributed to combinations of organism's behaviour (e.g. feedback between water chemistry and organisms, predator - prey interactions) and physical processes (e.g. wind-induced turbulence, internal seiches, currents). On the other hand, organisms and parameters of the microbial food web are often studied under the assumption that epilimnetic waters are horizontally homogeneous, at least in the pelagic zone. According to this hypothesis, also in relatively large lakes (surface in the order of $10^{2} \mathrm{~km}^{2}$ ) samples for dissolved and particulate organic matter, seston, chlorophyll and picoplankton are often taken only for a single site and the measures from this station are considered to be representative of the entire lake.

With this research is offered an analysis of spatial variance of seston, dissolved (DOC) and particulate (POC) organic matter, Chlorophyll- $a$ (Chl) and of autotrophic (APP) and heterotrophic (HPP) picoplankton in Lago Maggiore, a large deep oligotrophic lake in Northern Italy. With a two-year data set we evaluated whether and to what extent the horizontal homogeneity assumption is acceptable in a water body of that size and shape.

\section{METHODS}

\subsection{Study site}

Lago Maggiore is a deep oligotrophic subalpine lake (surface area $212 \mathrm{~km}^{2}, \mathrm{z}_{\max } 372 \mathrm{~m}$ ) in Northern Italy (de Bernardi et al. 1996). Many papers documented its trophic evolution in the last 50 years (e.g. Mosello \& Ruggiu 1985; Manca et al. 1992) and its present oligotrophic conditions after the restoration process (Calderoni et al. 1998). The lake is narrow, elongated in a north-south direction, and irregular in shape due to the presence of bays and side arms (Shoreline Development Index, DL = 3.29) (Fig. 1). It is feed by 13 main tributaries, two of them (Ticino River, Northern edge, and Toce River, Western harm edge) convey $134 \mathrm{~m}^{3} \mathrm{~s}^{-1}$ which accounts for $71 \%$ (yearly average of period 1978 2001) of total water inflow. The very shape of its basin is thus a potentially important determinant of the heterogeneous distribution of particles and organisms (de Bernardi et al. 1984).

\subsection{Sampling}

Samples for horizontal heterogeneity study were collected in the pelagic zone along seven transects, with a total of 18 sampling stations, crossing the main axes of Lago Maggiore (Fig. 1). Samples were seasonally taken during years 2000 and 2001 from 0-20 m layer (approximately corresponding to the photic zone), with an integrating sampler which collects a 5 litre sample in a single operation (Bertoni, pat. 96/A 000121). In addition, monthly (in autumn and winter) and fortnightly (in 
spring and summer) samplings were performed at the station of maximum depth (station 5 in Fig. 1).

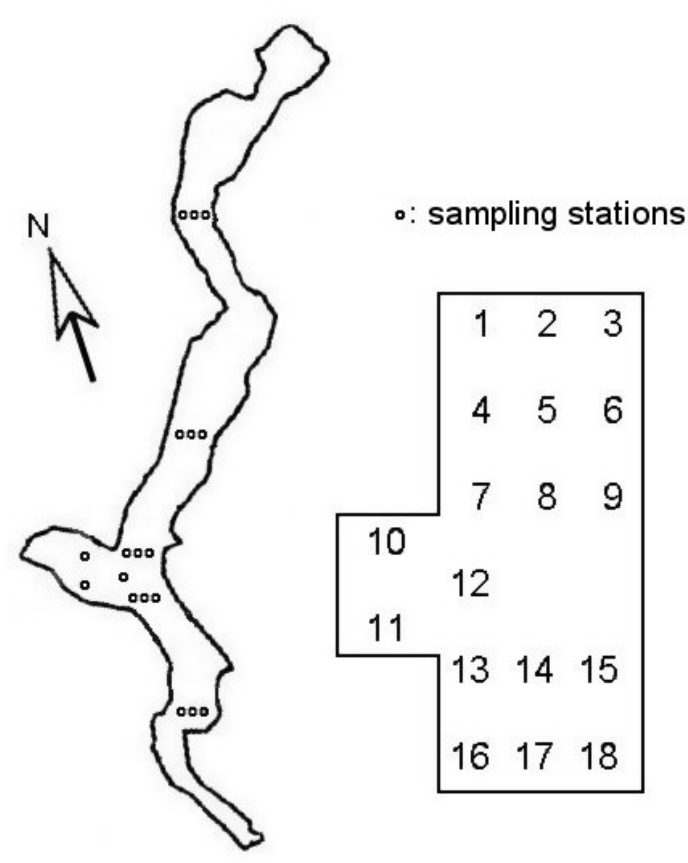

Fig. 1. Location of sampling stations in Lago Maggiore and position of corresponding data in tables 1 and 2 .

\subsection{Analytical methods}

Duplicate subsamples where filtered through $\mathrm{GF} / \mathrm{C}$ filters (Whatman) previously combusted at $450{ }^{\circ} \mathrm{C}$ for 3 hours and weighted. The filters where used to measure the total seston gravimetrically (Sartorius, 3311 microscale) and to perform Particulate Organic Carbon (POC) analyses by $\mathrm{CHN}$ Elemental Analyser (Carlo Erba, ANA 1500) (Bertoni 1978). Dissolved Organic Carbon (DOC) was calculated subtracting POC from Total Organic Carbon (TOC), measured with a Shimadzu (5000A) TOC analyser.

Samples of HPP and APP were immediately fixed using $0.2 \mu \mathrm{m}$ filtered cacodylate-buffered formaldehyde (final concentration $2 \% \mathrm{vol} / \mathrm{vol}$ ). To evaluate APP and HPP abundance, 1 to $5 \mathrm{ml}$ sample was filtered through $0.2 \mu \mathrm{m}$ Anopore filter. HPP were counted after DAPI ( $\alpha$, 6-diamino-2-phenylindole) staining (final concentration $0.2 \% \mathrm{wt} / \mathrm{vol}$ ) following Porter \& Feig (1980). At least 400 bacterial cells were counted on at least 10 fields in individual filters. APP were counted by autofluorescence of phycobiliproteins under blue and green light (Zeiss Axioplan microscope equipped with an HBO $100 \mathrm{~W}$ lamp, a Neofluar $100 \times$ objective $1.25 \times$ additional magnification and filter sets for blue (BP450490, FT510, LP520) and green (BP510-560, FT 580, LP590) light excitation). Chlorophyll- $a$ (Chl) was fluorometrically determined by Perkin-Elmer LS-2 Filter Fluorometer in duplicate subsamples, filtered through GF/C (Whatman), after pigment extraction with methanol (Talling \& Driver 1961; Holm-Hansen \& Riemann 1978).

\subsection{Heterogeneity index}

We defined the heterogeneity index (HI) according to Knauer et al. (2000) as a measure of the spatial heterogeneity of a variable at a given time as:

$$
\mathrm{HI}=\frac{\sqrt{\mathrm{S}_{\mathrm{s}}^{2}-\mathrm{S}_{\mathrm{m}}^{2}}}{\text { mean concentration }} \times 100 \%
$$

where $\mathrm{S}_{\mathrm{s}}$ is the "spatial" standard deviation among concentrations measured at the 18 sampling stations. In Eq. 1 it is assumed that analytical variability and spatial variability add in quadrature. The error of the measure is

$$
\mathrm{S}_{\mathrm{m}}=\mathrm{S}_{\mathrm{r}} / \sqrt{2}
$$

where $S_{r}$ is the standard deviation of replicated analyses of the same sample. $\mathrm{S}_{\mathrm{m}}$ is the correction for the component of $\mathrm{S}_{\mathrm{s}}$ attributable to the analytical variability. For each sampling date, $S_{r}$ is calculated from the differences between duplicate samples at each station,

$$
\mathrm{S}_{\mathrm{r}}^{2}=\sum_{\mathrm{i}=1}^{18} \sum_{\mathrm{j}=1}^{2}\left(\mathrm{x}_{\mathrm{i}, \mathrm{j}}-\overline{\mathrm{x}}_{\mathrm{i}}\right)^{2} / 18
$$

where $\mathrm{x}_{\mathrm{j}, 1}$ and $\mathrm{x}_{\mathrm{j}, 2}$ are the measurements at station $\mathrm{i}$, and where

$$
\overline{\mathrm{x}}_{\mathrm{i}}=\left(\mathrm{x}_{\mathrm{i}, 1}+\mathrm{x}_{\mathrm{i}, 2}\right) / 2 \text {. }
$$

The heterogeneity index (HI) thus computed is meaningful when the spatial heterogeneity is much larger than the analytical variability. However, when these values are comparable, the estimated spatial heterogeneity may largely be an expression of the analytical variability. Then the true spatial heterogeneity is likely smaller and the analytical variability can be viewed as the upper limit of HI.

\section{RESULTS AND DISCUSSION}

During years 2000 and 2001 the seasonal evolution of seston and TOC (Fig. 2, upper panel), chlorophyll- $a$ and bacterial number (Fig. 2, lower panel) followed the path observed in previous years (Bertoni \& Callieri 1993), with all parameters peaking in spring and summer. The most striking feature of the study period is the seston peak of November 2000, related to an exceptional flood event which lasted from October $14^{\text {th }}$ till October $24^{\text {th }}$ rising the lake level of about $4 \mathrm{~m}$ above the mean level (Ambrosetti et al. 2001). Seston was composed by $93 \%$ of inorganic particles immediately after the flood while the average of the previous months of 2000 was $71 \%$.

The flood event did not influence to the same extent the parameters under study: despite seston increased, organic carbon, chlorophyll- $a$, APP and HPP did not show any maxima mirroring that of seston. 

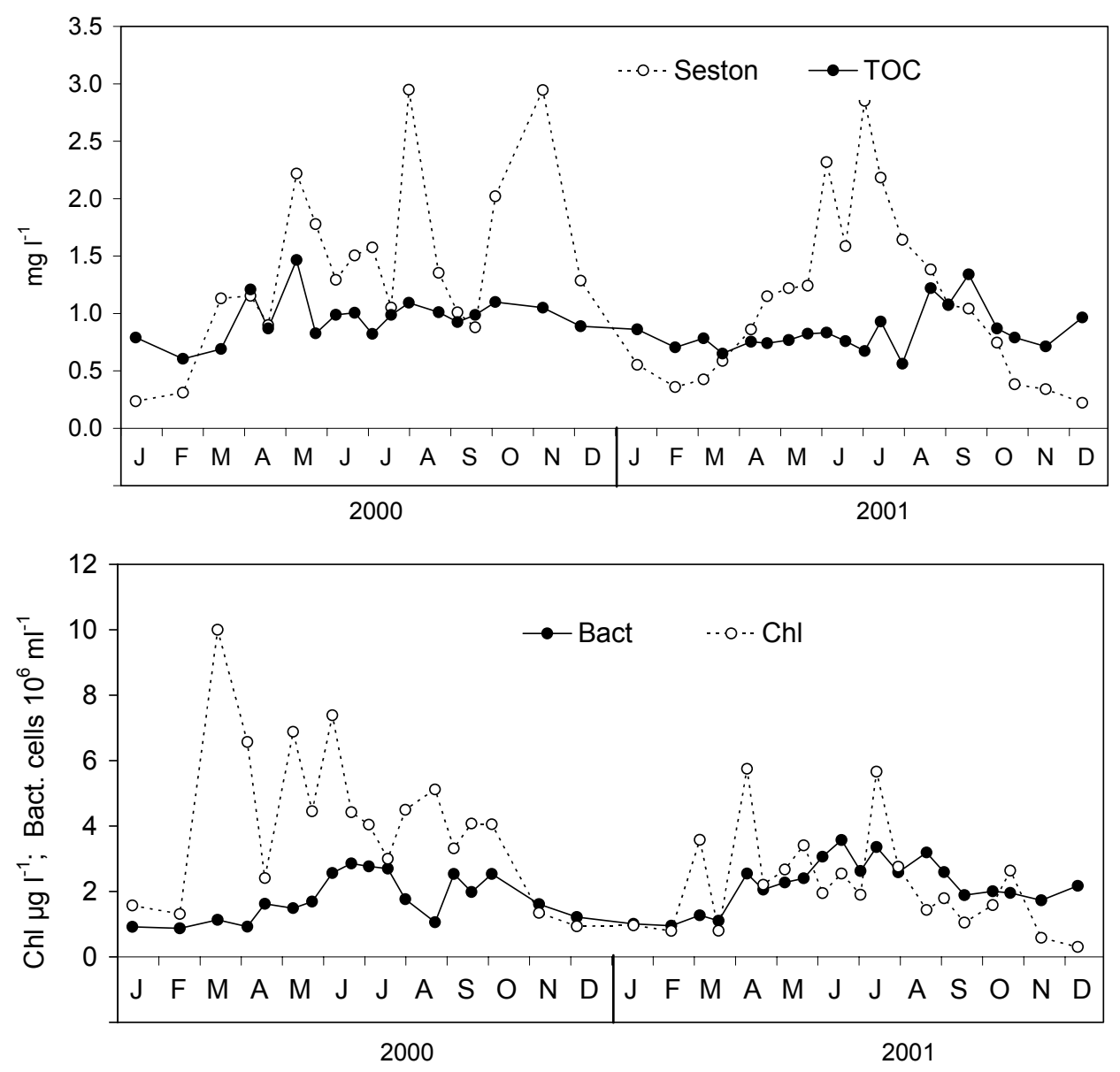

Fig. 2. Seasonal variation of Seston $\left(\mathrm{mg}^{-1}\right)$ and Total Organic Carbon (TOC: $\mathrm{mg}^{-1}$ ) (upper panel), Chlorophyll- $a\left(\mathrm{Chl}: \mu \mathrm{g}{ }^{-1}\right)$ and bacterial number (Bact.: cells $10^{6} \mathrm{ml}^{-1}$ ) (lower panel), in the euphotic zone of Lago Maggiore, during years 2000 and 2001.

In November and December there were not evident flood-induced alterations of the variables considered here. Thus, the data collected for horizontal heterogeneity study appear well in context with the time series data set, with the exception of November 2000.

The heterogeneity index (HI, Fig. 3) provides an estimate of the spatial heterogeneity corrected by the component which can be ascribed to analytical variability, i.e. the variability between two subsamples.

The HI values show differences among the parameters and with the season. In general the lake appears more homogeneous in autumn (Fig. 3). The data of November 2000, taken immediately after the flood, show that this phenomenon, although increasing the inlake concentration at least of seston, occurred with an intensity such to stir the upper layers and to homogeneously distribute the particles conveyed to the lake.

Among the particles related variables, POC and Chl resulted as the most heterogeneously distributed. This hold true also for seston, which is, however, mainly of biogenic origin in Lago Maggiore (Bertoni \& Callieri 1989) except during important floods. The heterogene- ity of $\mathrm{Chl}$ and POC decreased from winter to autumn. During the spring and summer of both years POC and Chl concentrations were $5-8$ times and $5-6$ times, respectively, higher than in winter. According to HI seasonal distribution of POC and Chl, their heterogeneity resulted higher when their concentration was lower. A possible explanation of this result is that in winter, when there is no production of new organic particles, any rare and small patch of detrital particles residual of previous season production, may result in high heterogeneity. Nevertheless, comparing non-productive and productive seasons it achieved a comparison between populations of particles with different densities. It is impossible to exclude completely that the HI we used, as the several indices proposed to compare the spatial aggregation of populations of unequal densities, do not contain mathematical artifacts bringing to misleading interpretations (Downing 1991).

As for the horizontal distribution of the picoplanktonic organisms, the spatial heterogeneity of the heterotrophic fraction (HPP) abundance resulted lower than the analytical variability in all samplings. This result suggests that the bacterial abundance from DAPI esti- 


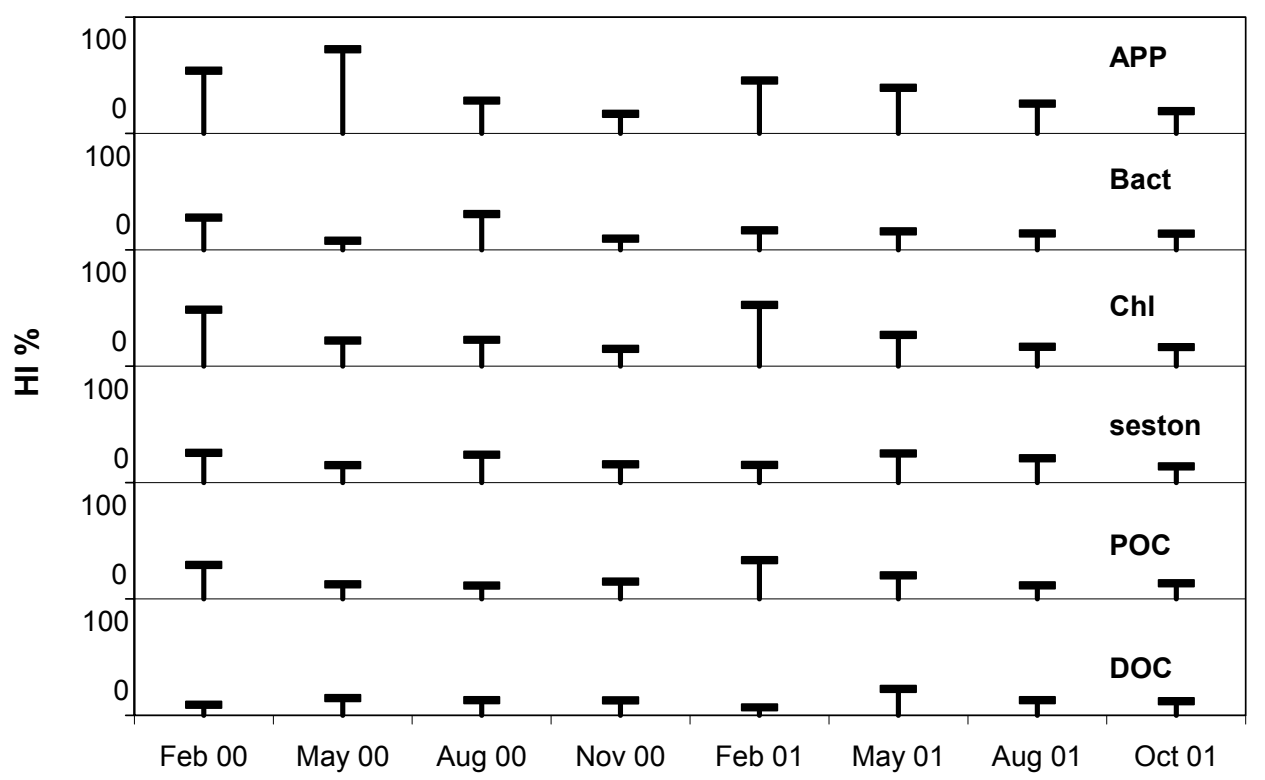

Fig. 3. Histograms of HI \% for the different variables.

mates does not allow to highlight a spatial heterogeneity of bacterial community, also because of the low specificity of this method. It has, in fact, a delayed response to changes in bacterial abundance not allowing the discrimination of non-living "ghosts" or not-growing cells (Søndergaard 2000). The spatial heterogeneity of bacterial community could be better evaluated from changes in population diversity at genetic level (Yannarell et al. 2003).

The APP horizontal heterogeneity was high in winter and spring in both years and lower than the analytical variability only in autumn 2001 .

To provide a visual assessment of the presence and of the spatial distribution of heterogeneity were prepared tables, schematically miming the shape of the lake. Figure 1 shows the correspondence between the sampling station location in the lake map and the schematic tables. In such tables marked in bold are the values where the concentration falls above the upper $95 \%$ confidence limit for variance associated to the analytical error (i.e., above the interval [1.m. $\pm \mathrm{t}$ (a.v.)], where $1 . \mathrm{m}$. is the lake mean concentration, $\mathrm{t}=2.11$ (for $\mathrm{P}=0.05$ and $\mathrm{df}=17$ ) and a.v. is the analytical variability). The stations in bold are those where the variability due to spatial heterogeneity significantly exceeded the analytical variability, i.e. where the average concentration was significantly higher respect to the homogeneous portion of the lake.

While the spatial heterogeneity of DOC, seston, autotrophic and heterotrophic picoplankton did not show any space-time pattern, the POC and Chlorophyll$a$ concentration exhibited a recurrent trend (Tab. 1, 2). It appears evident that both variables had significantly higher values in spring and summer samplings at the eastern side of the lake.
The eastward gradient of increasing POC and Chlorophyll- $a$ can result from patches formation due to differences in phytoplanktonic production. This indicate a decline, although small, of the trophic state along the east coast of the lake. This decline can be due to the nutrient inputs to the lake mainly coming from the east coast (Tab. 3). The possibility that such distribution is an effect of a wind promoted accumulation is unlikely due to the shape of Lago Maggiore, lying in a deep valley north - south oriented as the dominant winds (Ambrosetti et al. 2001).

\section{CONCLUSIONS}

The horizontal heterogeneity of some variables related to microbial food chain is a measurable attribute of Lago Maggiore. Its occurrence affects particulate more than dissolved fraction and is unevenly distributed during the seasons. The spatial heterogeneity is higher in winter particularly for $\mathrm{Chl}$ and APP, when the concentration of both variables is lower. This is probably linked more to the residuals from the spoilage of patches of the previous season than to episodic growth, unlikely in winter. No indication can be inferred on bacterial horizontal heterogeneity in this lake since the analytical variance of bacteria counts always exceeded the spatial variance. To gather such information a qualitative approach should be considered. Only Chl and POC (in this lake mainly autochthonous) showed an heterogeneity pattern recurrent in time (spring and summer) and location (east coast) of occurrence. The localization of the part of drainage basin contributing the major nutrient input is consistent with the hypothesis that such input is the driving event of the observed heterogeneity. 
Tab. 1. Particulate Organic Carbon concentration (POC, $\mu \mathrm{g} \mathrm{C} 1^{-1}$ ) in 18 stations of Lago Maggiore during years 2000 and 2001.
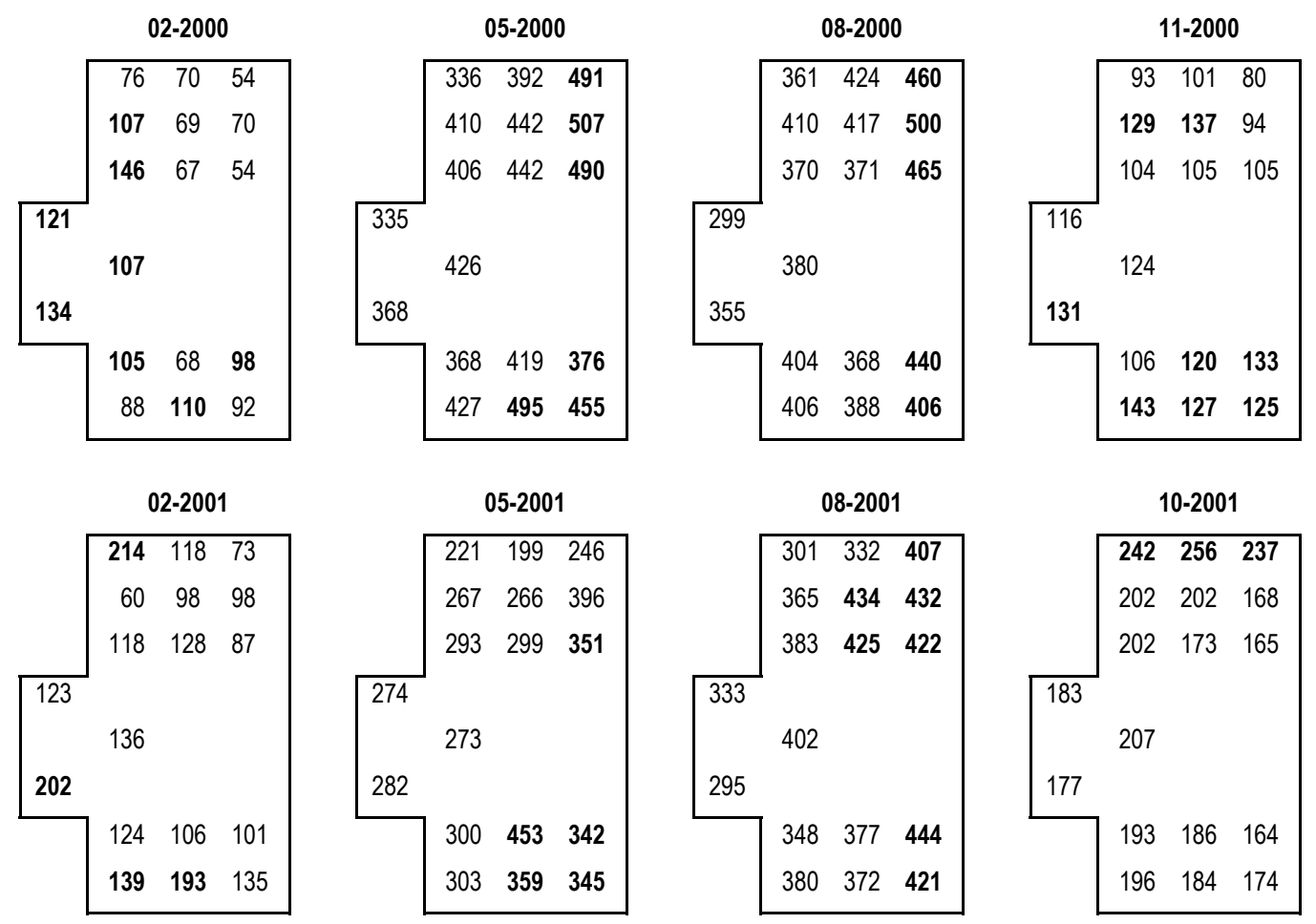

Tab. 2. Chlorophyll- $a$ concentration (Chl- $\left.a, \mu \mathrm{gl}^{-1}\right)$ in 18 stations of Lago Maggiore during years 2000 and 2001.
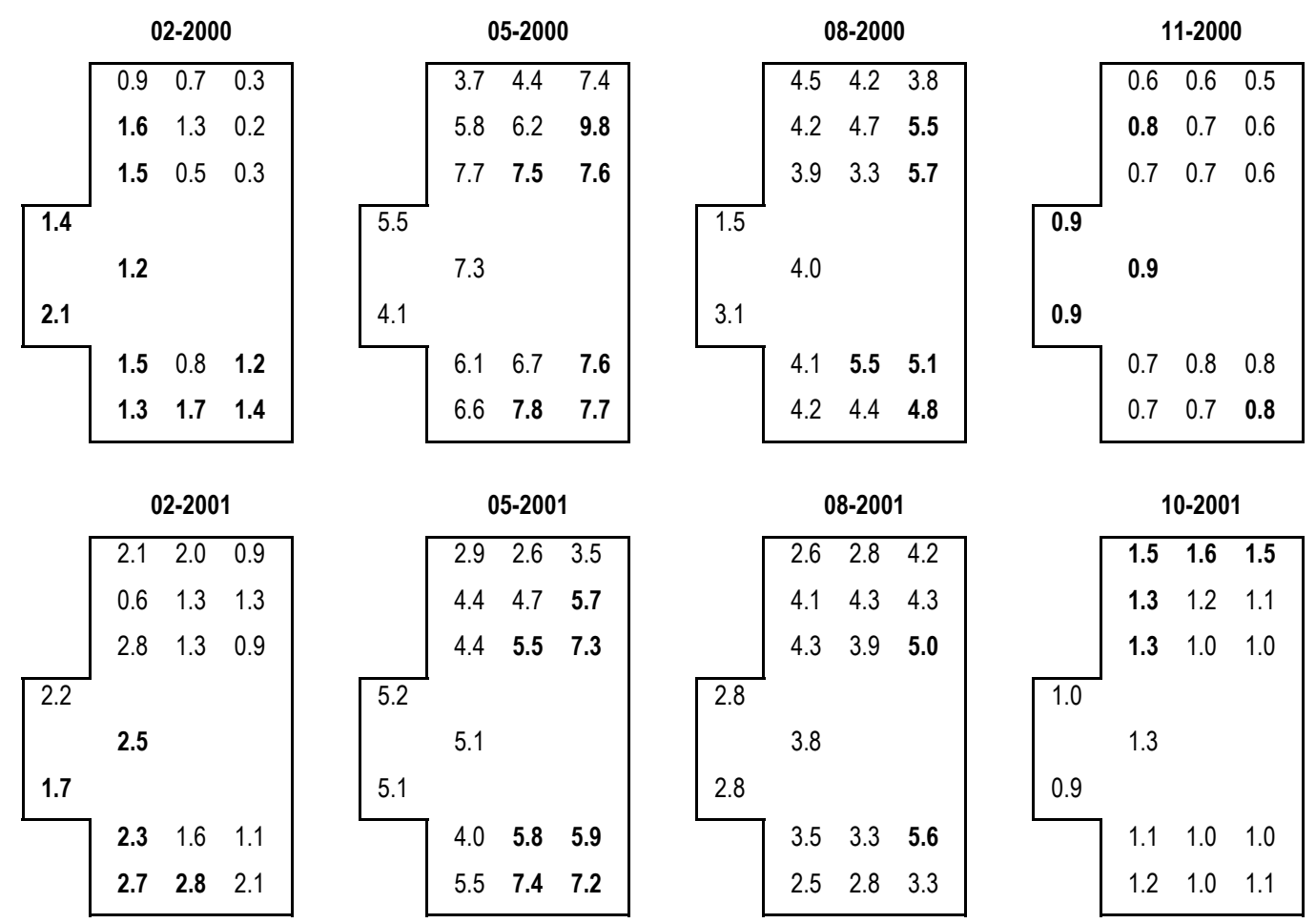
Tab. 3. Areal contribution of total $\mathrm{N}$ and total $\mathrm{P}$ from drainage basin of Lago Maggiore (average of years 20002001 data) (Calderoni et al. 2001).

\begin{tabular}{lc}
\hline & Total N $\left(\mathrm{g} \mathrm{m}^{-2} \mathrm{y}^{-1}\right)$ \\
Northern basin (Switzerland) & 1.504 \\
Western basin (Piedmont, Italy) & 1.612 \\
Eastern basin (Lombardy, Italy) & 2.300 \\
& \\
Northern basin (Switzerland) & Total P $\left(\mathrm{g} \mathrm{m}^{-2} \mathrm{y}^{-1}\right)$ \\
Western basin (Piedmont, Italy) & 0.015 \\
Eastern basin (Lombardy, Italy) & 0.038 \\
\hline
\end{tabular}

The large flood event occurred during this research did not produce a larger spatial variance of dissolved and of particulate matter of microscopic size. It rather resulted in higher homogeneity of the epilimnetic zone of the lake.

The observed magnitude and persistence of horizontal heterogeneity indicates that a single sampling point cannot be used for lake-scale characterization, at least for some variable which are of paramount importance in assessing the trophic status of the lake. Fairly, a sufficient number of distinct samples must be collected to quantify the spatial variance of seston, POC, Chl and APP. Furthermore, since we did not base sampling times on the occurrence of major meteorological phenomenon and sampling site on particular hydrological feature, it seems likely that the degree of heterogeneity that we observed may be a common occurrences in lakes such as Lago Maggiore. Further studies, conducted with higher spatial and temporal resolution, are needed to quantify specific mechanisms controlling the spatial distribution of microscopic size components of the food chain.

\section{ACKNOWLEDGMENTS}

We are grateful to Mario Contesini and Stefano Vanetti for their field work and in particular to Mario Contesini for his technical assistance in the laboratory.

\section{REFERENCES}

Ambrosetti, W., L. Barbanti, A. Ferrari \& A. Rolla. 2001. Meteorologia dell'areale lacustre In: C.N.R. Istituto Italiano di Idrobiologia, Ricerche sull'evoluzione del Lago Maggiore. Aspetti limnologici. Programma quinquennale 1998-2002. Campagna 2001. Ed. R. Bertoni, Commissione Internazionale per la protezione delle acque italosvizzere: $12-17$.

Bertoni, R. 1978. Automatic determination of carbon and nitrogen in suspended matter of natural water with Carlo Erba $1106 \mathrm{CHN}$ elemental analyzer. Mem. Ist. ital. Idrobiol., 36: 297-301.

Bertoni, R. \& C. Callieri. 1989. Organic matter and decomposers in Lago Maggiore: a pluriannual study. Mem. Ist. ital. Idrobiol., 46: 145-172.

Bertoni, R. \& C. Callieri. 1993. Organic carbon trend during the oligotrophication of Lago Maggiore. In : R. De Bernardi, R. Pagnotta \& A. Pugnetti (Eds.), Strategies for lake ecosystems beyond 2000. Mem. ist. ital. Idrobiol., 52: 191205.

Calderoni, A., A. Pranzo \& G. Tartari. 1998. Indagini sull'ambiente pelagico: chimica lacustre. In: C.N.R. Istituto Italiano di Idrobiologia, Ricerche sull'evoluzione del Lago Maggiore. Aspetti limnologici. Campagna 1997. Relazione finale per il quinquennio. Ed. Commissione Internazionale per la protezione delle acque italo-svizzere: 41-47.

Calderoni, A., A. Pranzo \& G. Tartari. 2001. Apporti chimici dai tributari. In: C.N.R. Istituto Italiano di Idrobiologia, Ricerche sull'evoluzione del Lago Maggiore. Aspetti limnologici. Programma quinquennale 1998-2002. Campagna 2001. Commissione Internazionale per la protezione delle acque italo-svizzere: 18-34.

de Bernardi, R., A. Calderoni \& R. Mosello. 1996. Environmental problems in Italian lakes, and lakes Maggiore and Orta as successful examples of correct management leading to restoration. Verh. int. Ver. Limnol., 26: 123-138.

de Bernardi, R., G. Giussani \& E. Grimaldi. 1984. Lago Maggiore. In: F.B. Taub (Ed.), Lakes and Reservoirs, Elsevier, Amsterdam, Vol. 23: 247-266.

Downing, J.A. 1991. Biological and physical heterogeneity in lakes. In: J. Kolasa \& S. Pickett (Eds), Ecological heterogeneity. Springer-Verlag, New York: 160-180.

George, D.G. \& S.I. Heaney. 1978. Factors influencing the spatial distribution of phytoplankton in a small productive lake. J. Ecol., 66: 133-155.

George, D.G. \& D.H. Jones. 1987. Catchment effects on the horizontal distribution of phytoplankton in five of Scotland's largest freshwater lochs. J. Ecol.,75: 43-59.

Holm-Hansen, O. \& B. Riemann. 1978. Chlorophyll-a determination: improvements in methodology. Oikos, 30: 438-447.

Knauer, K., H.M. Nepf, \& H.F. Hemond. 2000. The production of chemical heterogeneity in Upper Mystic Lake. Limnol. Oceanogr., 45: 1647-1654.

Laybourn Parry, J., J. Olver, A. Rogerson, P.L. Duverge. 1990. The temporal and spatial patterns of protozooplankton abundance in a eutrophic temperate lake. Hydrobiologia, 203: 99-110.

Malone, B.J. \& D.J. McQueen. 1983. Horizontal patchiness in zooplankton populations in two Ontario kettle lakes. Hydrobiologia, 99: 101-124.

Manca, M., A. Calderoni, R. Mosello. 1992. Limnological research in Lago Maggiore: studies on hydrochemistry and plankton. In: P. Guilizzoni, G. Tartari \& G. Giussani (Eds), Limnology in Italy. Mem. Ist. ital. Idrobiol., 50: 171-200.

Mosello, R. \& D. Ruggiu. 1985. Nutrient load, trophic condition and restoration prospects of Lake Maggiore. Internat. Rev. ges. Hydrobiol., 70: 63-75.

Platt, T., L. Dickie, \& R. Trietes. 1970. Spatial heterogeneity of phytoplankton in a near-shore environment. J. Fish. Res. Bd Can., 27: 1453-1473.

Porter, K.G. \& Y.S. Feig. 1980. The use of DAPI for identifying and counting aquatic microflora. Limnol. Oceanogr., 25: 943-948.

Søndergaard, M. 2000. Bacterioplankton: how many and how active? Verh. int. Ver. Limnol., 27: 859-865.

Talling, J.F. \& D. Driver. 1961. Some problems in the estimation of chlorophyll- $a$ in phytoplankton. Proc. $10^{\text {th }}$ Pac. Sci. Cong., Honolulu: 142-146.

Yannarell, A.C., A.D. Kent, G.H. Lauster, T.K. Kratz \& E.W. Triplett. 2003. Temporal patterns in bacterial communities in three temperate lakes of different trophic status. Microb. Ecol., 46: 391-405. 